This article was downloaded by: [National Taiwan University]

On: 2 June 2009

Access details: Access Details: [subscription number 906385847]

Publisher Informa Healthcare

Informa Ltd Registered in England and Wales Registered Number: 1072954 Registered office: Mortimer House, 37-41 Mortimer Street, London W1T 3JH, UK

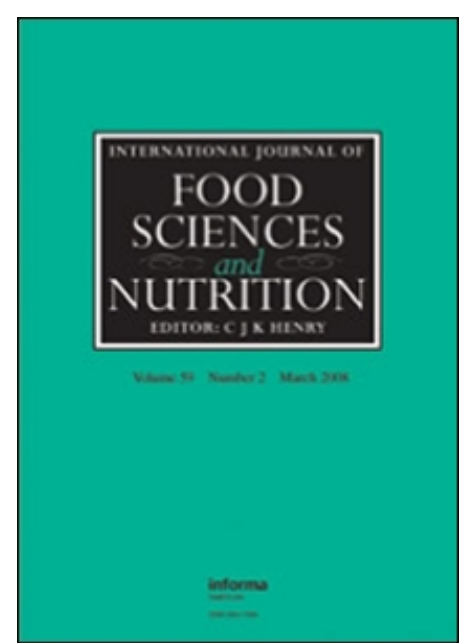

International Journal of Food Sciences and Nutrition

Publication details, including instructions for authors and subscription information:

http://www.informaworld.com/smpp/title content=t713425816

\title{
Lactic fermentation and antioxidant activity of Zingiberaceae plants in Taiwan
}

I-Nan Chen a; Chang-Chai Ng a; Chung-Yi Wang a; Tsu-Liang Chang a

a Department of Horticulture, National Taiwan University, Taipei, Taiwan, Republic of China

First Published on: 22 October 2008

To cite this Article Chen, I-Nan, Ng, Chang-Chai, Wang, Chung-Yi and Chang, Tsu-Liang(2008)'Lactic fermentation and antioxidant activity of Zingiberaceae plants in Taiwan',International Journal of Food Sciences and Nutrition,99999:1,

To link to this Article: DOI: $10.1080 / 09637480802375531$

URL: http://dx.doi.org/10.1080/09637480802375531

\section{PLEASE SCROLL DOWN FOR ARTICLE}

Full terms and conditions of use: http://www.informaworld.com/terms-and-conditions-of-access.pdf

This article may be used for research, teaching and private study purposes. Any substantial or systematic reproduction, re-distribution, re-selling, loan or sub-licensing, systematic supply or distribution in any form to anyone is expressly forbidden.

The publisher does not give any warranty express or implied or make any representation that the contents will be complete or accurate or up to date. The accuracy of any instructions, formulae and drug doses should be independently verified with primary sources. The publisher shall not be liable for any loss, actions, claims, proceedings, demand or costs or damages whatsoever or howsoever caused arising directly or indirectly in connection with or arising out of the use of this material. 


\title{
Lactic fermentation and antioxidant activity of Zingiberaceae plants in Taiwan
}

\author{
I-NAN CHEN, CHANG-CHAI NG, CHUNG-YI WANG \& \\ TSU-LIANG CHANG
}

Department of Horticulture, National Taiwan University, Taipei, Taiwan, Republic of China

\begin{abstract}
The present study evaluated functional properties of lactic-fermented ginger products. Three Zingiberaceae species were used as the substrate for fermentation using three lactic acid bacteria. The fermentation process ended $35-40 \mathrm{~h}$ after inoculation and reached a $\mathrm{pH}$ value of 3.5-4.0. Total antioxidant performances were $68-75 \%$, and were best observed using Bifidobacterium longum as the starter in three ginger samples. DPPH scavenging was on average $70 \%$, with free radical anion scavenging and peroxide removal effects of $30.6 \%$ and $43.7 \%$, respectively. The product acceptance survey showed that the $100 \%$ fermented juice without a mixture with non-fermented ginger juice obtained the highest score in overall performance. The lactic-fermented Vanoverberghia and Hedychium ginger species retained an antioxidant activity and DPPH scavenging activity of on average $70 \%$. This study may suggest a new way of ginger food processing with high functionality. Also, it may help to popularize the growing and processing of endemic ginger plants in Taiwan.
\end{abstract}

Keywords: Antioxidant, lactic fermentation, reducing power, Zingiberaceae

\section{Introduction}

The Zingiberaceae plants, commonly known as ginger, have 50 genera and over 1,300 species worldwide (Williams et al. 2004). Most of them have strong aromatic and medicinal properties. The rhizome of the Zingiberaceae plant in powder form, turmeric, a source from Curcuma sp., is widely applied as a food additive in many Asian countries. Medicinal functions for treatment of diseases are also widely recorded in many traditional remedies (Ammon 1991; Charles and Charles 1992; Miquel et al. 2002).

Over the past few decades, there are increasing cases of isolation of novel lactic acid bacteria strains that exert a beneficial health effect to humans. Such strains are termed probiotic. Probiotics are major lactic acid bacteria; after ingestion in certain numbers, they help to promote health benefits beyond inherent basic nutrition in a certain number (Parker 1974). Lactic-fermented food has also been identified in previous studies, with evidence demonstrating its functionality in promoting gastrointestinal health (Parker 1974; Sarrela et al. 2002).

Correspondence: Tsu-Liang Chang, Department of Horticulture, National Taiwan University, 1 Roosevelt Road Section 4, Taipei 10617 Taiwan, ROC. Tel: 8862 33664850. Fax: 8862 23661441. E-mail: ghouse@ntu.edu.tw 
Zingiberaceae plants are rich in functional chemicals, including terpenes, alcohols, ketones, flavonoids, carotenoids and phytoestrogens (Habsah et al. 2000; SkrzypezacJankun et al. 2000). These components have been reported for many antifungal, antioxidant, insecticidal and anti-inflammatory activities (Sirat 1994; Sirat and Liamen 1995; Sirat et al. 1996; Mau et al. 2003; Suhaj 2006). Some widely consumed ginger has a long human food history worldwide, based on previous investigation on Taiwan endemic ginger plants' properties in antioxidant and antimicrobial activities (Chen et al. 2008), and the present study evaluates functional properties of a new lactic-fermented ginger product prototype. The fermentation condition and functional characteristics were investigated. Vanoverberghia sp. is an endemic species found in local Lanyu island in 2000. Hydychium is used as a traditional remedy for flu and fever by aborigines in Taiwan since ancient times (Funakoshi and Ohashi 2000). The previous study by Chen et al. (2008) indicates their antioxidative and free radical reducing properties. Vanoverberghia is only found in Lanyu island and there has been a lack of incentive to use it commercially since its discovery. To promote their value and processing, lactic fermentation may be an optimum way to preserve its nutrient and functional properties.

Despite previous study indicating the antimicrobial activity of ginger extract (Habsah et al. 2000; Wilson et al. 2005; Chen et al. 2008), our preliminary test on ginger juice supports growth of lactic acid bacteria. This encouraging result may turn ordinary ginger material into a high-value added product. The initial conditions of the ginger material are presented in Table I. The viable bacteria count is $4.5 \times 10^{3}$ colonyforming units (CFU)/ml. Notably, the total solid soluble is $2.8^{\circ}$ Brix; preliminary experiments gave a significant growth of lactic acid bacteria, and thus no additional carbon source was given. The present study is hoped to contribute a positive outcome in promoting the use of endemic ginger plants in Taiwan.

\section{Materials and methods}

\section{Materials preparation}

Three gingers (Curcuma domestica Valet, Hedychium coronarium Koenig and Vanoverberghia sasakiana $\mathrm{H}$. Funak. \& H. Ohashi) were obtained from a traditional market and Taitung Agricultural Improvement Station, Council of Agriculture. The selection of these species is based on their high functionality as an antioxidant indicated in our previous study (Chen et al. 2008). After arrival at the laboratory, samples were washed and peeled. Afterward, $150 \mathrm{ml}$ sterile water was added to 150 of peeled gingers and then blended into juice using a commercial food processor (CookPot JF-102, RTmart, Taipei, ROC) under room temperature. The ginger juice was directly use for inoculation without any further treatment.

Table I. Initial conditions of Curcuma ginger juice material $(n=3)$.

\begin{tabular}{ll}
\hline Measurement & \multicolumn{1}{c}{ Result } \\
\hline Viable bacteria count & $4.5 \pm 0.8 \times 10^{3} \mathrm{CFU} / \mathrm{ml}$ \\
Titratable acid (citric acid) & $0.26 \pm 0.04 \%$ \\
pH value & 6.4 \\
Total solid soluble & $2.8 \pm 0.3^{\circ}$ Brix \\
\hline
\end{tabular}


Strains Lactobacillus acidophilus BCRC 14079, Lactobacillus casei subsp. casei BCRC 12248 and Bifidobacterium longum BCRC 14602 were purchased from Bioresources Collection and Research Center, Hsinchu, ROC. The strains were subcultured twice on a MRS (de Man, Rogosa and Sharpe) plate (BD Difco, NJ, USA) according to the user manual.

\section{Total soluble solids, titratable acid and $\mathrm{pH}$ determination}

Fermented ginger juice was filtered with an 11-cm diameter Whatman \#1 filter (Post Apple Scientific, Inc., North East, PA, USA). The total soluble solids were determined using a Hand Refractometer (ATAGO, Tokyo, Japan). The recorded data were presented as ${ }^{\circ}$ Brix. Titratable acid (citrus acid) was determined using the method described by Policegoudra and Aradhya (2007), as it is the major titratable component of ginger juice. Fermented juice was filtered with a Whatman \#1 filter, and $20 \mathrm{~g}$ filtered juice was titrated using $0.1 \mathrm{M} \mathrm{NaOH}$ at room temperature to a $\mathrm{pH}$ value of 8.1. Fermented juice was filtered with a Whatman \#1 filter and measured by a pH Vision 6071 microcomputer (Jenco Electronics Ltd., Taiwan, ROC).

\section{Fermentation of ginger juice}

Strains L. acidophilus BCRC 14079, L. casei subsp. casei BCRC 12248 and B. longum BCRC 14602 were used as fermentation starters based on the previous study of Chen et al. (2008) and Tien et al. (2005). The subcultured starters were cultured in MRS (de Man, Rogosa and Sharpe plate) broth for $24 \mathrm{~h}$ at $37^{\circ} \mathrm{C}$ and reached an $\mathrm{OD}_{600}$ of 1.0 , which is equivalent to $10^{6} \mathrm{CFU} / \mathrm{ml}$. Five milliliters of starter $\left(5 \times 10^{6} \mathrm{CFU} / \mathrm{ml}\right)$ was inoculated into $150 \mathrm{ml}$ ginger juice. The fermentation process was carried at $37^{\circ} \mathrm{C}$ for $60 \mathrm{~h}$. To standardize the growing conditions of fermentation and to avoid growth of other pathogens, fermented ginger juice with a viable bacterial count greater than $10^{8} \mathrm{CFU} / \mathrm{ml}$ was heated at $90^{\circ} \mathrm{C}$ for $1 \mathrm{~min}$ on heating plate according to Chen (2002). The viable bacteria count was carried out by the serial dilution plate count method. The fermented samples were dried with a freeze-dryer (Christ Freeze dryer Alpha 1-2/ LD-2, Vacuum pump RZ-5; Kuhner, Basel, Switzerland) for $48 \mathrm{~h}$. Dried samples were subsequently milled using a commercial hand-carry milling machine (TSKU928S EUPA, Hypermart, Taipei, Taiwan). The preparation of methanolic extract was described by Chen et al. (2008). The samples were ready for further testing.

\section{Total antioxidant activity}

The antioxidant capacity of samples was measured using the method as described by Miller and Rice-Evans (1997) and Arnao et al. (2001) with little modification. Peroxidase (4.4 units/ml; Sigma-Aldrich, St Louis, MO, USA), $\mathrm{H}_{2} \mathrm{O}_{2}(50 \mu \mathrm{M}$; Merck, Darmstadt, Germany), 2,2-azino-bis (3-ethylbenz-thiazoline-6-sulphonic acid) $(100 \mu \mathrm{M}$; Sigma-Aldrich) and distilled water $(1 \mathrm{ml})$ were mixed and kept in the dark for $1 \mathrm{~h}$ for reaction. One milliliter of plant extract was subsequently added and determined for absorbance at $734 \mathrm{~nm}$. The antioxidant capacity was calculated by the following formula:

$$
\text { Total antioxidant activity }(\%)=\left[1-\left(A_{734 \mathrm{~nm}} \text { sample } / A_{734 \mathrm{~nm}} \text { control }\right)\right] \times 100 \%
$$




\section{Reducing power}

The reducing power was measured according to the method described by Duh and Yen (1997). One milliliter of plant extract, phosphate buffer $(0.2 \mathrm{M}, \mathrm{pH} 6.6,0.5 \mathrm{ml}$; Merck), and potassium hexacyanoferrate solution ( $1 \% \mathrm{v} / \mathrm{w}, 2.5 \mathrm{ml}$; Merck) were placed in a test tube and heated at $50^{\circ} \mathrm{C}$ for $20 \mathrm{~min}$. The tube was cooled on ice and $0.5 \mathrm{ml} \mathrm{10 \%} \mathrm{trichloroacetic} \mathrm{acid} \mathrm{(Merck)} \mathrm{was} \mathrm{added.} \mathrm{After} \mathrm{centrifugation} \mathrm{at} \mathrm{3,000} \times \mathrm{g}$ for $10 \mathrm{~min}$, an $1 \mathrm{ml}$ aliquot of supernatant was mixed with $1 \mathrm{ml}$ distilled water and $0.1 \mathrm{ml}$ ferric chloride $(0.1 \%$; Merck), and then the reaction maintained for $10 \mathrm{~min}$. Finally, the absorbance at $700 \mathrm{~nm}$ was measured. Increased absorbance of the reaction mixture indicates higher reducing power.

\section{DPPH free radical scavenging activity}

The DPPH (Sigma-Aldrich) removal method was as referred by Shimada et al. (1992). Briefly, $1 \mathrm{ml}$ methanolic extract and $5 \mathrm{ml}$ freshly prepared $0.1 \mathrm{mM} \mathrm{DPPH}$ methanolic solution were thoroughly mixed and kept in the dark for $60 \mathrm{~min}$. The absorbance of the reaction mixture at $517 \mathrm{~nm}$ was measured with a spectrophotometer. The blank was prepared by replacing the ginger extract with methanol $(1 \mathrm{ml})$. The percentage of free radical scavenging activity was calculated as follows:

$$
\text { Scavenging effect }(\%)=\left[1-\left(A_{517 \mathrm{~nm}} \text { sample } / A_{517 \mathrm{~nm}} \text { blank }\right)\right] \times 100 \%
$$

\section{Scavenging effect against superoxide anion radicals}

Using Robak and Gryglewski's (1988) method, $120 \mu \mathrm{M}$ phenazine methosulfate (Sigma-Aldrich), $936 \mu \mathrm{M} \alpha$-nicotinamide-adenine-dinucleotide (Sigma-Aldrich) and $300 \mu \mathrm{M}$ nitro-blue tetrazolium (Sigma-Aldrich) solution were mixed with $50 \mu 1$ fermented ginger juice. After $5 \mathrm{~min}$ reaction, the absorbance at $560 \mathrm{~nm}$ was measured, the percentage of free radical scavenging activity was calculated as follows:

$$
\text { Scavenging effect } \left.(\%)=\left[1-A_{560 \mathrm{~nm}} \text { sample } / A_{560 \mathrm{~nm}} \text { blank }\right)\right] \times 100 \%
$$

\section{Scavenging effect against hydrogen peroxide}

The method was that referred to Pick and Mizel (1981). Fifty microliters of fermented ginger juice was added with $50 \mu \mathrm{l}$ of $5 \mathrm{mM} \mathrm{H}_{2} \mathrm{O}_{2}$ and mixed thoroughly. After $20 \mathrm{~min}$ reaction under room temperature, $100 \mu \mathrm{l}$ horseradish peroxidasephenol red (HRPase, $300 \mu \mathrm{g} / \mathrm{ml}$; phenol red, $4.5 \mathrm{mM}$; Sigma-Aldrich) was added and reacted for $10 \mathrm{~min}$. Absorption at $610 \mathrm{~nm}$ was recorded and calculated as follows:

$$
\text { Scavenging effect }(\%)=\left[1-\left(A_{610 \mathrm{~nm}} \text { sample } / A_{610 \mathrm{~nm}} \text { blank }\right)\right] \times 100 \%
$$

\section{Sensory testing}

Sensory testing of the product was evaluated by 25 students with a food processing background from Department of Horticulture, National Taiwan University. Fermented ginger was mixed with fresh ginger juice in $0: 1,1: 1$ and 1:0 ratios. The testers were 

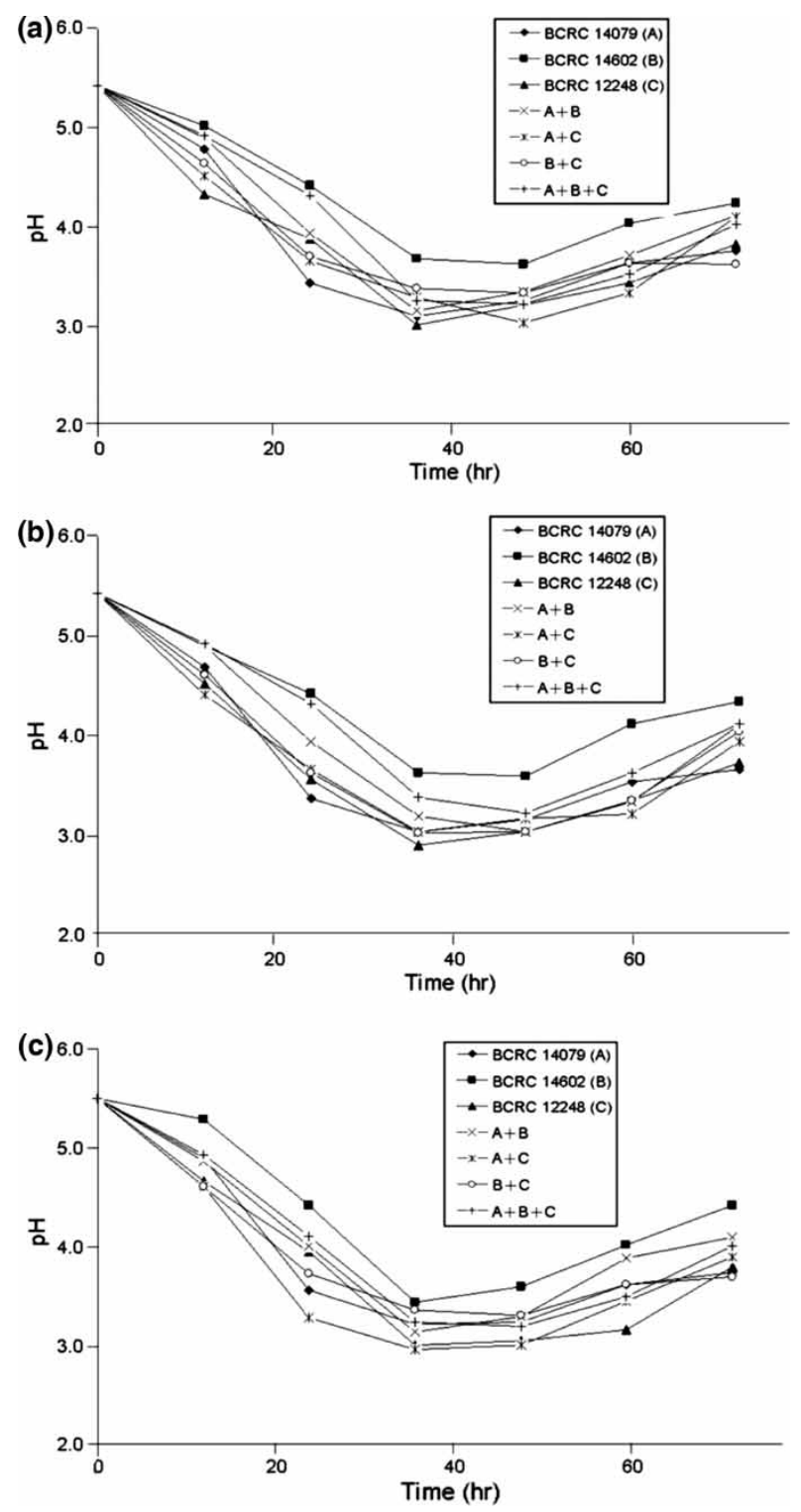

Figure 1. Changes in $\mathrm{pH}$ value during fermentation by different starters. (a) Curcuma domestica Valet. (b) Hedychium coronarium Koenig. (c) Vanoverberghia sasakiana H. Funak. \& H. Ohashi. Reported values are the mean \pm standard deviation $(n=3)$.

requested to evaluate the products in terms of color, aroma, sweetness, tartness and overall acceptability along a scale of zero to seven, with zero indicating the lowest and seven the highest levels of acceptance.

\section{Statistical analysis}

Experimental results were averages of triplicate analysis. The data were recorded as the mean \pm standard deviation and analysis was by the statistical analysis system 
Table II. Total antioxidant activity of lactic-fermentation of gingers.

\begin{tabular}{llcc}
\hline & \multicolumn{3}{c}{ Total antioxidant capacity (\%) } \\
\cline { 2 - 4 } & $\begin{array}{c}\text { C. domestica } \\
\text { Valet }\end{array}$ & $\begin{array}{c}\text { H. coronarium } \\
\text { Koenig }\end{array}$ & $\begin{array}{c}\text { V. sasakiana H. Funak. } \\
\text { \& H. Ohashi }\end{array}$ \\
\hline L. acidophilus (A) & $65.7 \pm 3.9^{\mathrm{B}, \mathrm{b}}$ & $70.4 \pm 2.8^{\mathrm{AB}, \mathrm{a}}$ & $66.7 \pm 4.5^{\mathrm{A}, \mathrm{ab}}$ \\
B. longum (B) & $71.6 \pm 5.2^{\mathrm{A}, \mathrm{a}}$ & $75.2 \pm 4.8^{\mathrm{A}, \mathrm{a}}$ & $68.2 \pm 2.8^{\mathrm{A}, \mathrm{a}}$ \\
L. casei (C) & $66.9 \pm 3.82^{\mathrm{B}, \mathrm{a}}$ & $67.5 \pm 5.2^{\mathrm{BC}, \mathrm{a}}$ & $65.3 \pm 3.7^{\mathrm{AB}, \mathrm{a}}$ \\
$\mathrm{A}+\mathrm{B}$ & $63.8 \pm 4.3^{\mathrm{B}, \mathrm{a}}$ & $66.9 \pm 5.8^{\mathrm{BC}, \mathrm{a}}$ & $61.2 \pm 3.9^{\mathrm{ABC}, \mathrm{a}}$ \\
$\mathrm{A}+\mathrm{C}$ & $62.5 \pm 3.8^{\mathrm{BC}, \mathrm{a}}$ & $62.1 \pm 3.2^{\mathrm{C}, \mathrm{a}}$ & $55.5 \pm 5.1^{\mathrm{C}, \mathrm{b}}$ \\
$\mathrm{B}+\mathrm{C}$ & $64.9 \pm 5.8^{\mathrm{B}, \mathrm{a}}$ & $60.7 \pm 2.8^{\mathrm{B}, \mathrm{a}}$ & $58.8 \pm 4.9^{\mathrm{BC}, \mathrm{a}}$ \\
A+B+C & $57.4 \pm 4.8^{\mathrm{C}, \mathrm{a}}$ & $63.5 \pm 5.3^{\mathrm{BC}, \mathrm{a}}$ & $55.6 \pm 4.2^{\mathrm{C}, \mathrm{b}}$ \\
BHA (butylated hydroxyanisole) & $94.7 \pm 4.7$ & & \\
$\alpha-$ Tocopherol & $95.3 \pm 5.5$ & & \\
\hline
\end{tabular}

Contents of BHA and $\alpha$-tocopherol are $40 \mathrm{mg} / \mathrm{l}$. Reported values are the mean \pm standard deviation $(n=3)$. Data bearing different superscript letters in the same column (uppercase) and in the same row (lowercase) are significantly different $(P<0.05)$.

(SAS Inc., Cary, NC, USA). One-way analysis of variance was performed by analysis of variance procedures. Significant differences between means were determined by Duncan's multiple-range tests. Results were considered statistically significant at $P<0.05$.

\section{Results and discussion}

Changes in $\mathrm{pH}$ in a 60 -h fermentation process were observed as shown in Figure 1. The $\mathrm{pH}$ value of majority of inoculated substrates decreased from $\mathrm{pH} 5.5$ to 3.0, especially BCRC 12248. The lowest $\mathrm{pH}$ level of the fermentation process occurred $38 \mathrm{~h}$ after inoculation. Notably, BCRC14602-fermented substrates retained the highest $\mathrm{pH}$ value among samples, with the lowest $\mathrm{pH}$ of 4.0 observed in Vanoverberghia samples (Figure 1c).

Table III. Reducing power of lactic-fermentation of gingers.

\begin{tabular}{llll}
\hline & \multicolumn{2}{c}{ OD $_{700}$} \\
\cline { 2 - 4 } & $\begin{array}{c}\text { C. domestica } \\
\text { Valet }\end{array}$ & $\begin{array}{c}\text { H. coronarium } \\
\text { Koenig }\end{array}$ & $\begin{array}{c}\text { V. sasakiana H. Funak. } \\
\text { \& H. Ohashi }\end{array}$ \\
\hline L. acidophilus (A) & $0.18 \pm 0.03^{\mathrm{F}, \mathrm{a}}$ & $0.20 \pm 0.02^{\mathrm{C}, \mathrm{a}}$ & $0.19 \pm 0.01^{\mathrm{C}, \mathrm{a}}$ \\
B. longum (B) & $0.30 \pm 0.01^{\mathrm{A}, \mathrm{a}}$ & $0.31 \pm 0.01^{\mathrm{A}, \mathrm{a}}$ & $0.28 \pm 0.02^{\mathrm{A}, \mathrm{a}}$ \\
L. casei (C) & $0.26 \pm 0.02^{\mathrm{BC}, \mathrm{a}}$ & $0.22 \pm 0.03^{\mathrm{BC}, \mathrm{b}}$ & $0.25 \pm 0.03^{\mathrm{AB}, \mathrm{a}}$ \\
$\mathrm{A}+\mathrm{B}$ & $0.21 \pm 0.03^{\mathrm{CD}, \mathrm{a}}$ & $0.19 \pm 0.02^{\mathrm{C}, \mathrm{a}}$ & $0.21 \pm 0.02^{\mathrm{C}, \mathrm{a}}$ \\
$\mathrm{A}+\mathrm{C}$ & $0.19 \pm 0.03^{\mathrm{EF}, \mathrm{a}}$ & $0.16 \pm 0.01^{\mathrm{D}, \mathrm{a}}$ & $0.18 \pm 0.02^{\mathrm{C}, \mathrm{a}}$ \\
$\mathrm{B}+\mathrm{C}$ & $0.28 \pm 0.02^{\mathrm{AB}, \mathrm{a}}$ & $0.19 \pm 0.02^{\mathrm{C}, \mathrm{c}}$ & $0.22 \pm 0.01 \mathrm{~B}^{\mathrm{C}, \mathrm{b}}$ \\
A+B+C & $0.22 \pm 0.01^{\mathrm{DE}, \mathrm{b}}$ & $0.15 \pm 0.01^{\mathrm{D}, \mathrm{c}}$ & $0.19 \pm 0.02^{\mathrm{C}, \mathrm{a}}$ \\
BHA (butylated hydroxyanisole) & $0.52 \pm 0.03$ & & \\
$\alpha-$ Tocopherol & $0.85 \pm 0.02$ & & \\
\hline
\end{tabular}

Contents of BHA and $\alpha$-tocopherol are $40 \mathrm{mg} / 1$. Reported values are the mean \pm standard deviation $(n=3)$. Data bearing different superscript letters in the same column (uppercase) and in the same row (lowercase) are significantly different $(P<0.05)$. 
Table IV. Scavenging effects of lactic-fermentation of gingers against DPPH radicals.

\begin{tabular}{lccc}
\hline & \multicolumn{3}{c}{ Scavenging effect (\%) } \\
\cline { 2 - 4 } & $\begin{array}{c}\text { C. domestica } \\
\text { Valet }\end{array}$ & $\begin{array}{c}\text { H. coronarium } \\
\text { Koenig }\end{array}$ & $\begin{array}{c}\text { V sasakiana H. Funak. } \\
\text { \& H. Ohashi }\end{array}$ \\
\hline L. acidophilus (A) & $62.5 \pm 2.7^{\mathrm{B}, \mathrm{ab}}$ & $65.7 \pm 2.5^{\mathrm{B}, \mathrm{a}}$ & $60.3 \pm 1.5^{\mathrm{B}, \mathrm{b}}$ \\
B. longum (B) & $70.4 \pm 3.1^{\mathrm{A}, \mathrm{a}}$ & $71.8 \pm 2.2^{\mathrm{A}, \mathrm{a}}$ & $72.3 \pm 2.7^{\mathrm{A}, \mathrm{a}}$ \\
L. casei (C) & $69.1 \pm 2.2^{\mathrm{A}, \mathrm{a}}$ & $66.6 \pm 1.9^{\mathrm{B}, \mathrm{ab}}$ & $65.5 \pm 1.8^{\mathrm{B}, \mathrm{a}}$ \\
$\mathrm{A}+\mathrm{B}$ & $63.8 \pm 1.9^{\mathrm{B}, \mathrm{a}}$ & $66.7 \pm 3.8^{\mathrm{B}, \mathrm{a}}$ & $64.8 \pm 1.4^{\mathrm{B}, \mathrm{a}}$ \\
A+C $+\mathrm{C}+\mathrm{C}$ & $60.8 \pm 3.6^{\mathrm{B}, \mathrm{a}}$ & $58.6 \pm 2.5^{\mathrm{C}, \mathrm{a}}$ & $63.4 \pm 2.7^{\mathrm{B}, \mathrm{a}}$ \\
A+B+C & $68.5 \pm 4.3^{\mathrm{A}, \mathrm{a}}$ & $67.4 \pm 1.7^{\mathrm{AB}, \mathrm{a}}$ & $70.5 \pm 2.4^{\mathrm{A}, \mathrm{a}}$ \\
BHA (butylated hydroxyanisole) & $85.4 \pm 1.8$ & $60.2 \pm 3.2^{\mathrm{C}, \mathrm{a}}$ & $55.9 \pm 3.1^{\mathrm{C}, \mathrm{a}}$ \\
$\alpha-$ Tocopherol & $84.4 \pm 1.3$ & & \\
\hline
\end{tabular}

Contents of BHA and $\alpha$-tocopherol are $40 \mathrm{mg} / 1$. Reported values are the mean \pm standard deviation $(n=3)$. Data bearing different superscript letters in the same column (uppercase) and in the same row (lowercase) are significantly different $(P<0.05)$.

The antioxidant activity of three samples using different combination of starters ranged from $55 \%$ to $75 \%$. The performances were best observed using B. longum as the starter in three ginger samples (Table II) - gingers fermented with B. longum showed higher antioxidant activity. The results obtained from the mixture were $55.5-66.9 \%$.

In reducing power, three gingers using $B$. longum as starter exhibited higher activity ( 0.30 absorbance) than those of a mixture, which averaged 0.22 (Table III). A similar result was also found in DPPH scavenging activity, B. longum used as the starter in three ginger substrate remains highest in scavenging activity ( $>70 \%$ ) (Table IV), with the mixture groups showing an average of merely $63 \%$. In superoxide radical and hydrogen peroxide scavenging properties, B. longum displayed higher levels in anion and hydrogen peroxide radical removal effects using three substrates, averaging $29 \%$ and $40 \%$, respectively (Tables $\mathrm{V}$ and $\mathrm{VI}$ ). The mixture groups merely gave an average of $18 \%$ and $25 \%$, respectively.

Table V. Scavenging effects of lactic-fermentation of gingers against superoxide anion radicals.

\begin{tabular}{llcc}
\hline & \multicolumn{3}{c}{ Scavenging effect (\%) } \\
\cline { 2 - 4 } & $\begin{array}{c}\text { C. domestica } \\
\text { Valet }\end{array}$ & $\begin{array}{c}\text { H. coronarium } \\
\text { Koenig }\end{array}$ & $\begin{array}{c}\text { V. sasakiana H. Funak. } \\
\text { \& H. Ohashi }\end{array}$ \\
\hline L. acidophilus (A) & $13.6 \pm 2.3^{\mathrm{E}, \mathrm{ab}}$ & $15.6 \pm 1.9^{\mathrm{C}, \mathrm{a}}$ & $11.7 \pm 1.8^{\mathrm{E}, \mathrm{b}}$ \\
B. longum (B) & $30.6 \pm 2.5^{\mathrm{A}, \mathrm{a}}$ & $29.4 \pm 2.4^{\mathrm{A}, \mathrm{a}}$ & $28.2 \pm 3.1^{\mathrm{A}, \mathrm{a}}$ \\
L. casei (C) & $18.6 \pm 1.6^{\mathrm{CD}, \mathrm{a}}$ & $16.3 \pm 1.7^{\mathrm{C}, \mathrm{a}}$ & $15.3 \pm 2.3^{\mathrm{CD}, \mathrm{a}}$ \\
$\mathrm{A}+\mathrm{B}$ & $16.5 \pm 2.7^{\mathrm{D}, \mathrm{a}}$ & $14.6 \pm 1.3^{\mathrm{C}, \mathrm{a}}$ & $13.8 \pm 1.5^{\mathrm{DE}, \mathrm{a}}$ \\
$\mathrm{A}+\mathrm{C}$ & $13.8 \pm 1.5^{\mathrm{E}, \mathrm{a}}$ & $11.4 \pm 1.6^{\mathrm{D}, \mathrm{a}}$ & $14.6 \pm 1.9^{\mathrm{CD}, \mathrm{a}}$ \\
$\mathrm{B}+\mathrm{C}$ & $22.9 \pm 1.8^{\mathrm{B}, \mathrm{a}}$ & $19.26 \pm 2.7^{\mathrm{B}, \mathrm{a}}$ & $21.49 \pm 1.8^{\mathrm{B}, \mathrm{a}}$ \\
A+B+C & $19.2 \pm 2.4^{\mathrm{C}, \mathrm{a}}$ & $15.8 \pm 1.6^{\mathrm{C}, \mathrm{b}}$ & $17.3 \pm 2.3^{\mathrm{C}, \mathrm{ab}}$ \\
BHA (butylated hydroxyanisole) & $46.7 \pm 1.6$ & & \\
$\alpha-$ Tocopherol & $55.8 \pm 2.2$ & & \\
\hline
\end{tabular}

Contents of BHA and $\alpha$-tocopherol are $40 \mathrm{mg} / 1$. Reported values are the mean \pm standard deviation $(n=3)$. Data bearing different superscript letters in the same column (uppercase) and in the same row (lowercase) are significantly different $(P<0.05)$. 
Table VI. Scavenging effects of lactic-fermentation of gingers against hydrogen peroxide.

\begin{tabular}{llcc}
\hline & \multicolumn{3}{c}{ Scavenging effect (\%) } \\
\cline { 2 - 4 } & $\begin{array}{c}\text { C. domestica } \\
\text { Valet }\end{array}$ & $\begin{array}{c}\text { H. coronarium } \\
\text { Koenig }\end{array}$ & $\begin{array}{c}\text { V. sasakiana H. Funak. } \\
\text { \& H. Ohashi }\end{array}$ \\
\hline L. acidophilus (A) & $32.7 \pm 2.6^{\mathrm{B}, \mathrm{a}}$ & $29.3 \pm 1.8^{\mathrm{B}, \mathrm{a}}$ & $27.5 \pm 3.2^{\mathrm{CD}, \mathrm{a}}$ \\
B. longum (B) & $40.3 \pm 1.9^{\mathrm{A}, \mathrm{ab}}$ & $36.4 \pm 2.4^{\mathrm{A}, \mathrm{b}}$ & $43.7^{\mathrm{BC}} \pm 2.6^{\mathrm{A}, \mathrm{a}}$ \\
L. casei (C) & $30.2 \pm 2.7^{\mathrm{BC}, \mathrm{a}}$ & $25.4 \pm 2.9^{\mathrm{BC}, \mathrm{b}}$ & $33.8^{\mathrm{B}} \pm 3.3^{\mathrm{B}, \mathrm{a}}$ \\
$\mathrm{A}+\mathrm{B}$ & $27.6 \pm 1.8^{\mathrm{DC}, \mathrm{a}}$ & $24.9 \pm 2.5^{\mathrm{C}, \mathrm{a}}$ & $24.8^{\mathrm{DE}, \mathrm{a}}$ \\
A+C & $21.5 \pm 1.9^{\mathrm{E}, \mathrm{a}}$ & $19.7 \pm 2.8^{\mathrm{D}, \mathrm{a}}$ & $23.6 \pm 2.7^{\mathrm{E}, \mathrm{a}}$ \\
$\mathrm{B}+\mathrm{C}$ & $29.2 \pm 2.4^{\mathrm{C}, \mathrm{a}}$ & $25.2 \pm 2.9^{\mathrm{C}, \mathrm{a}}$ & $25.9 \pm 2.2^{\mathrm{CDE}, \mathrm{a}}$ \\
A+B+C & $26.3 \pm 1.2^{\mathrm{D}, \mathrm{ab}}$ & $23.4 \pm 1.8^{\mathrm{C}, \mathrm{b}}$ & $29.5^{\mathrm{B}} \pm 2.5^{\mathrm{BC}, \mathrm{a}}$ \\
BHA (butylated hydroxyanisole) & $21.4 \pm 1.3$ & & \\
$\alpha-$ Tocopherol & $33.9 \pm 2.2$ & & \\
\hline
\end{tabular}

Contents of BHA and $\alpha$-tocopherol are $40 \mathrm{mg} / \mathrm{l}$. Reported values are the mean \pm standard deviation $(n=3)$. Data bearing different superscript letters in the same column (uppercase) and in the same row (lowercase) are significantly different $(P<0.05)$.

The product acceptance survey showed that the fermented juice obtained an overall performance of 4.21 points $(o p<0.05)$ (Table VII). Ginger juice without any treatment exhibits a pungent and unpleasant flavor and may lead to low acceptability. In color and aroma, all ratio combinations remain similar; however, the sweetness and tartness of product exhibited gradual changes when the ratio of fermented to fresh ginger decreases. It was therefore observed that, after fermentation, decreased tartness of the products may become a major factor for acceptance.

Various studies make use of fruit as a fermentation substrate. Tien et al. (2005) make use of sugar apple (Annona squamosa L.) as the fermented substrate. The fermented sugar apple juice exhibited DPPH scavenging efficiency as high of $88 \%$ and an iron chelating ability of $49 \%$. The acceptance survey also showed that the fermented juice mix with a fresh juice mixture ratio of 3:7 gained the highest overall performance. This is different to the result shown in this study, as tartness of fresh ginger juice reduced its acceptance. The starter used in this study also was similar to those used by Chen (2002), who found L. casei ssp. casei to be the optimal fermentation starter in carrot juice. Carrot juice fermentation led by Lactobacillus reached $\mathrm{pH} 3.8$ after $60 \mathrm{~h}$, an observation that is rather different from those in this study $(35-40 \mathrm{~h})$. Acceptance was higher in fermented gingers without a mixture with fresh ginger.

To compare the antioxidant activity of fermented product with previous studies, fresh Vanoverberghia and Hedychium methanol extracts, the fermented product, exhibited a decrease of $15-20 \%$ of antioxidant, which was previously $89 \%$ for both species (Chen et al. 2008); that is, as high as $65-75 \%$ of antioxidant and $70 \% \mathrm{DPPH}$ scavenging activity in the fermented product. This is worthy for promotion due to the additional function for gastrointestinal digestion brought by Lactobacillus. This study may suggest a new way of ginger food processing with dual functional property. Also, it would help to popularize growing and processing of endemic Zingiberaceae species. 
Table VII. Sensory and consumer test of fermented three ginger substrates.

\begin{tabular}{|c|c|c|c|c|c|c|c|}
\hline & $\begin{array}{l}\text { Fermented } \\
\text { ginger/fresh } \\
\text { ginger ratio }\end{array}$ & Color & Aroma & Acidity & Sweetness & Tartness & $\begin{array}{c}\text { Overall } \\
\text { acceptance }\end{array}$ \\
\hline \multirow[t]{3}{*}{ C. domestica Valet } & $0: 1$ & $4.39 \pm 1.62^{\mathrm{A}}$ & $4.25 \pm 2.21^{\mathrm{A}}$ & $4.33 \pm 2.14^{\mathrm{AB}}$ & $0.59 \pm 0.23^{\mathrm{C}}$ & $3.67 \pm 1.14^{\mathrm{C}}$ & $3.44 \pm 1.12^{\mathrm{C}}$ \\
\hline & $1: 1$ & $4.38 \pm 1.74^{\mathrm{A}}$ & $4.19 \pm 1.78^{\mathrm{A}}$ & $4.12 \pm 1.55^{\mathrm{A}}$ & $2.15 \pm 0.72^{\mathrm{A}}$ & $3.92 \pm 1.49^{\mathrm{BC}}$ & $3.75 \pm 1.02^{\mathrm{C}}$ \\
\hline & $1: 0$ & $4.29 \pm 1.38^{\mathrm{A}}$ & $4.13 \pm 1.47^{\mathrm{A}}$ & $3.97 \pm 1.76^{\mathrm{AB}}$ & $3.24 \pm 1.28^{\mathrm{A}}$ & $4.68 \pm 2.15^{\mathrm{AB}}$ & $4.02 \pm 0.93^{\mathrm{ABC}}$ \\
\hline \multirow[t]{3}{*}{ H. coronarium Koenig } & $0: 1$ & $4.47 \pm 1.53^{\mathrm{A}}$ & $4.59 \pm 1.33^{\mathrm{A}}$ & $3.50 \pm 1.52^{\mathrm{AB}}$ & $0.87 \pm 0.33^{\mathrm{C}}$ & $3.21 \pm 1.22^{\mathrm{BC}}$ & $3.32 \pm 1.83^{\mathrm{ABC}}$ \\
\hline & $1: 1$ & $4.62 \pm 1.86^{\mathrm{A}}$ & $4.38 \pm 2.04^{\mathrm{A}}$ & $3.55 \pm 1.35^{\mathrm{B}}$ & $1.98 \pm 0.92^{\mathrm{B}}$ & $4.43 \pm 1.68^{\mathrm{AB}}$ & $3.79 \pm 1.26^{\mathrm{ABC}}$ \\
\hline & $1: 0$ & $4.53 \pm 2.04^{\mathrm{A}}$ & $4.40 \pm 1.88^{\mathrm{A}}$ & $3.64 \pm 1.64^{\mathrm{AB}}$ & $3.88 \pm 1.58^{\mathrm{A}}$ & $4.65 \pm 1.62^{\mathrm{AB}}$ & $4.22 \pm 1.63^{\mathrm{AB}}$ \\
\hline \multirow{4}{*}{$\begin{array}{l}\text { V. sasakiana H. Funak. \& } \\
\text { H. Ohashi }\end{array}$} & $0: 1$ & $4.35 \pm 1.83^{\mathrm{A}}$ & $4.25 \pm 1.63^{\mathrm{A}}$ & $3.35 \pm 1.74^{\mathrm{AB}}$ & $0.69 \pm 0.24^{\mathrm{C}}$ & $3.75 \pm 1.61^{\mathrm{BC}}$ & $3.27 \pm 0.84^{\mathrm{C}}$ \\
\hline & $1: 1$ & $4.48 \pm 2.11^{\mathrm{A}}$ & $4.20 \pm 1.72^{\mathrm{A}}$ & $3.80 \pm 1.63^{\mathrm{B}}$ & $1.80 \pm 0.53^{\mathrm{B}}$ & $4.05 \pm 1.37^{\mathrm{BC}}$ & $3.66 \pm 1.32^{\mathrm{BC}}$ \\
\hline & $1: 0$ & $4.53 \pm 1.87^{\mathrm{A}}$ & $4.05 \pm 1.68^{\mathrm{A}}$ & $4.25 \pm 2.25^{\mathrm{A}}$ & $3.25 \pm 1.47^{\mathrm{A}}$ & $5.76 \pm 0.85^{\mathrm{A}}$ & $4.39 \pm 1.41^{\mathrm{A}}$ \\
\hline & Average & $4.44^{-}$ & 4.27 & 3.83 & 2.05 & 4.24 & \\
\hline
\end{tabular}

Score of zero indicates the lowest acceptance, seven indicates the highest acceptance. Reported values are the means \pm standard deviation $(n=3)$. Data bearing different uppercase superscript letters in the same column are significantly different $(P<0.05)$ 


\section{Acknowledgements}

The authors would like to thank Taitung Agricultural Improvement Station, Council of Agriculture, ROC for their contribution of ginger samples. Assistance of local growers from different county in species collection was also very much appreciated.

\section{References}

Ammon HPT. 1991. Pharmacology of Curcuma longa. Planta Med 57:1-7.

Arnao MB, Cano A, Acosta M. 2001. The hydrophilic and lipophilic contribution to total antioxidant activity. Food Chem 73:239-244.

Charles V, Charles SX. 1992. The use and efficacy of Azadirachta indica ADR ('Neem') and Curcuma longa ('Turmeric') in scabies. A pilot study. Trop Geogr Med 44:178-181.

Chen IC. 2002. Studies on manufacturing of lactic acid fermented fruit and vegetable mixed juice. Taipei, Taiwan: Institute of Food Sciences and Technology, National Taiwan University.

Chen IN, Chang CC, Ng CC, Wang CY, Shyu YT, Chang TL. 2008. Antioxidant and antimicrobial activity of Zingiberaceae plants in Taiwan. Plant Foods Hum Nutr 63:15-20.

Duh PD, Yen GC. 1997. Antioxidative activity of three herbal water extracts. Food Chem 60:639-645.

Funakoshi H, Ohashi H. 2000. Vanovergberghia sasakiana H. Funak. \& H. Ohashi (Zingiberaceae), a new species and a new generic record for the flora of Taiwan. Taiwania 45:270-275.

Habsah M, Amran M, Mackeen MM, Lajis NH, Kikuzaki H, Nakatani H, Rahman A, Ghafar, Ali AM. 2000. Screening of Zingiberaceae extracts for antimicrobial and antioxidant activities. J Ethnopharmacol 72:403-410.

Mau J, Eric L, Lai YC, Wang NP, Chen CC, Chang CH, Chyau CC. 2003. Composition and antioxidant activity of the essential oil from Curcuma zedoaria. Food Chem 82:583-591.

Miller NJ, Rice-Evans CA. 1997. The relative contributions of ascorbic acid and phenolic antioxidants to the total antioxidant activity of orange and apple fruit juices and blackcurrant drink. Food Chem 60: 331-337.

Miquel J, Bernd A, Sempere JM, Diaz-Alperi J, Ramírez A. 2002. The curcuma antioxidants: Pharmacological effects and prospects for future clinical use. A review. Arch Gerontol Geriatr 34:37-46.

Parker RB. 1974. Probiotics, the other half of the antibiotic story. Anim Nutr Health 29:4-8.

Pick E, Mizel D. 1981. Rapid microassays for the measurement of superoxide and hydrogen peroxide production by macrophages in culture using an automatic enzyme immunoassay reader. J Immunol Methods 46:211-226.

Policegoudra RS, Aradhya SM. 2007. Biochemical changes and antioxidant activity of mango ginger (Curcuma amada Roxb.) rhizomes during postharvest storage at different temperatures. Postharv Biol Technol 46:189-194.

Robak J, Gryglewski RJ. 1988. Flavonoids are scavengers of superoxide anions. Biochem Pharmacol $37: 837-841$.

Sarrela M, Lähteenmäki L, Crittenden R, Salminen S, Mattila-Sandholm T. 2002. Gut bacteria and health foods-The European perspective. Int J Food Microbiol 78:99-117.

Shimada K, Fujikawa K, Yahara K, Nakamura T. 1992. Antioxidative properties of xanthan on the autooxidation of soybean oil in cyclodextrin. J Agric Food Chem 40:945-948.

Sirat HM. 1994. Study on the terpenoids of Zingiber ottensi. Planta Med 60:497.

Sirat HM, Liamen MR. 1995. Chemical constituents of Alpinia purpurata. Pertanika J Sci Tech 3:67-71.

Sirat HM, Rahman AA, Itokawa H, Morita H. 1996. Constituents of the rhizomes of two Alpinia species of Malaysia. Planta Med 62:188-189.

Skrzypezac-Jankun E, McCabe NP, Selman SH, Jankun J. 2000. Curcumin inhibits lipoxygenase by binding to its central cavity: Theoretical and X-ray evidence. Intl J Mol Med 6:521-526.

Suhaj M. 2006. Spice antioxidants isolation and their antiradical activity: a review. J Food Compos Anal 19:31-537.

Tien YY, Ng CC, Chang CC, Tseng WS, Kotwal S, Shyu YT. 2005. Studies on the lactic-fermentation of sugar apple (Annona squamosa L.) puree. J Food Drug Anal 13:377-381.

Williams KJ, Kress WJ, Manos PS. 2004. The phylogeny, evolution and classification of the genus Globba and Tribe Globbeae (Zingiberaceae): Appendages do matter. Am J Bot 91:100-114.

Wilson B, Abraham G, Manju VS, Mathew M, Vimala B, Sundaresan S, Nambisan S. 2005. Ethnopharmacological communication-Antimicrobial activity of Curcuma zedoaria and Curcuma malabarica tubers. J Ethnopharmacol 99:147-151. 